\title{
禹側下頻骨骨体部部分切除短衫術の筋国图学的研究
}

\author{
谷本辟三
}

\section{An electromyographic study on bilateral partial ostectomy of mandibular body}

Keizo Tanimoto

\section{样 \\ 反対咬合の5ち，骨格型に異常を認める下預勀突症に} 执いては，下䫑骨の切除や離断を行い，外科的に碩を移 轩させる方法か用いられている。

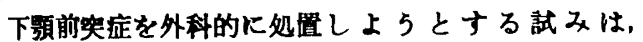
Hullihen (1849) ${ }^{1)}$ による初の報告以来, Blair (1907) ${ }^{2)}$, Harsha (1912)3), New $5(1941)^{4)}$, Dingman (1944) s), Thoma $(1963)^{6)}$ および Obwegeser $(1964)^{7)}$ らによって 発表されており，本邦です岡田 $(1932)^{8)}$ が全身麻助下 で口孟外から下頻骨骨体部切除を行って以来，多くの 人々によって垠告されてきた゚ー11). しかし, Goldstein $(1947)^{12)}$, Robinson ら (1961) ${ }^{13)}$ および Mills (1969) ${ }^{14)}$ らは，本应の治療には口腔外科と镉正科との協力が必 要であると述べている. 大阪橉科大学では，口腔外科，

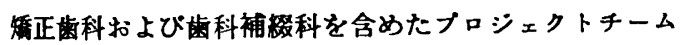
を組樴して治㞠にあたっている15).

ところで，本症の治療には咬合を形態学的に改善する ととすに, 口腔の諸機能を正常に雓持するために, 術後 の口腔機能の锶察を続けることが必要である。しかし， 下䫑前突症に関する研究においては，䪽顔面形態を顔面 および頭部 X線規格写真上で術前と術後について比較し ているすのがほとんどで16 27)，その機能を調べたものは きわめて少なく ${ }^{26)}$, ことに咀嚼筋の活動を筋奄図学的に 倹討したものには，下額を骨体部法および ObwegeserDal pont 法を用いて手術した下額前突症患者の術前と

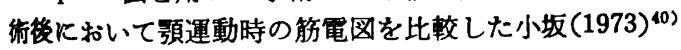
の報告があるだけである.

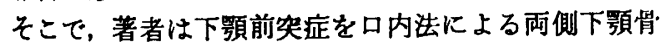
の骨体部における部分切除短縮術によって治療した症例 について，その術前と術後における咀嗅筋の筋活動を比 较して，下額前突症処直の評価ならびに改善に資するこ

大阪齿科大学口腔外科学教室第 2 講座（主任：岡野 博郎教授）

The Second Department of Oral Surgery, Osaka Dental University (Chief: Prof. Hakuro Okano) 受付日：昭和 55 年 11 月 12 日
竞 1 手術群に括ける情切除部位，切馀幅 および骨切除の非態

\begin{tabular}{|c|c|c|c|c|c|c|}
\hline \multirow[b]{2}{*}{ 症例番号 } & \multirow[b]{2}{*}{ 性: } & \multirow{2}{*}{$\begin{array}{l}\text { 年 } \\
\text { 战 }\end{array}$} & \multirow{2}{*}{$\begin{array}{l}\text { 骨切除 } \\
\text { 部 位 }\end{array}$} & \multicolumn{2}{|c|}{ 切除幅 } & \multirow{2}{*}{$\begin{array}{l}\text { 骨切除 } \\
\text { の形態 }\end{array}$} \\
\hline & & & & $\begin{array}{l}\text { 左㑡 } \\
(\mathrm{mm})\end{array}$ & $\begin{array}{l}\text { 右側 } \\
(\mathrm{mm})\end{array}$ & \\
\hline 1. & 男 & 19 & $\overline{6 / 6}$ & 12.0 & 12.0 & 台 形 \\
\hline 2. & 女 & 20 & $\overline{6} \overline{6}$ & 9.0 & 6.5 & 長方形 \\
\hline 3. & 男 & 23 & $\overline{5} 5$ & 6.5 & 6.5 & 長方形 \\
\hline 4. & 男 & 21 & $\overline{6 / 6}$ & 7.0 & 7.0 & 辰方形 \\
\hline 5. & 女 & 18 & $\overline{65156}$ & 15.0 & 15.0 & 台 形 \\
\hline 6. & 男 & 17 & $\overline{65 \mid 56}$ & 14. 0 & 14.0 & 台 形 \\
\hline 7. & 女 & 19 & $\overline{515}$ & 5.0 & 5.0 & V字形 \\
\hline 8. & 女 & 21 & $\overline{6 ! 6}$ & 11.0 & 11.0 & 台 形 \\
\hline 9. & 女 & 25 & $\overline{6 / 56}$ & 10.0 & 9.0 & 台 形 \\
\hline 10. & 男 & 17 & $\overline{6 / 6}$ & 7.5 & 12.5 & 台 形 \\
\hline
\end{tabular}

とを目的として本研究を行った。

\section{被検者}

\section{1. 手郝群}

本研究の対象とした症例は，大阪橉科大学付属病院に 下顎前突の改善を主訴として来䟚し, 口内法による両側 下影骨骨体部部分切除短縮術ならびにその術前，術後に それぞれ約 1 年間矯正㐘科で歯列矯正処置を受けた年峆 17 藏から 25 歳までの男女各 5 名合計 10 症例である（表 1 ).

なお，との患者も術前においてもまた術後において む，右側で咀謝する習惯がある症例を選んた。

また，各症例を，その手術内容から分類すると（表 1),

1）骨岈除部位については，a） $\overline{616}$ 部が最も多く， 5 例あり，b） $\overline{5 ! 5}$ 部执よび $\overline{65 \mid 56}$ は各 2 例ずつで， c）残りの 1 例は, $\overline{6} 5 \overline{6}$ 部である.

2) 歯槽頂部での骨切除幅については, 左右側のどち らの側においても $15.0 \mathrm{~mm}$ のものが最大で, 最小は $5.0 \mathrm{~mm}$ であり, $10.0 \mathrm{~mm}$ 以上のものが半数を占めて 
表 2 skcletal class 近分㬎（木卜，能山）に上る

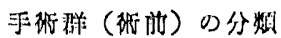

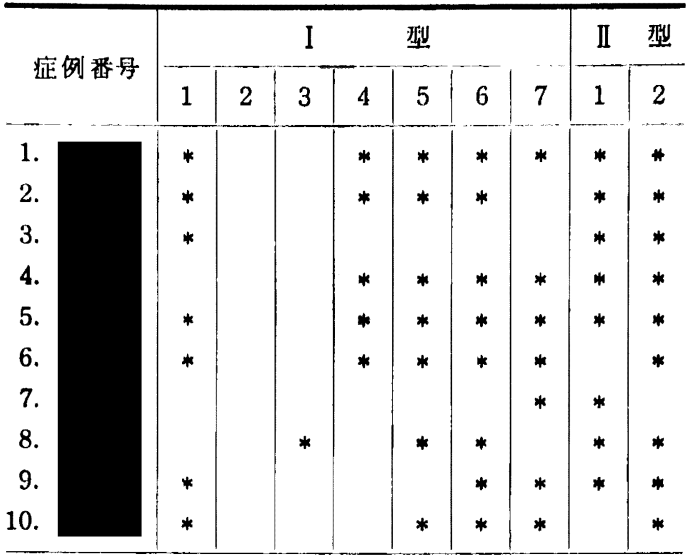

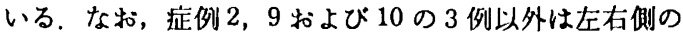
骨切除幅は同一であった。

3）骨切除部の形態について分類すると，a）台形の ものか多く， 5 例あり， b ）長方形のもの 4 例，c） V 字形のもの 1 例である.

また，対象とした各症例を骨恪型の下顎前劦怔分類 （木下，龍田）(5) によって分類すると（表 2)，

1）I 型では，a） $1 \cdot 3$ 類（下額骨の過成長）が 8 例，b） 4 類（下顎枝の異常）か 5 例， ） 5 類 (下顥 角の異常) か 7 例，d） 7 類（重直関係の買常）か７例 である。

2) II 型では，a） 1 類 (上類前米の居側傾斜) が 8 例，b） 2 類（下額前㽤の舌側傾斜）が 9 例である.

\section{2. 対照群}

正常な咬合を有し，かつ歯科次患をもたず，主として

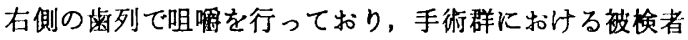
（患者）とほほ同年龄の男 3 名，女 2 名を選んで，対照 群の被検者とした。

\section{研究 方 法}

\section{1. 筋電図の記録とその分析}

\section{1) 記録方法}

シールドルーム内の椅子に被娭者を自然に座らせて, 市販のチューインガム（約 $3.5 \mathrm{~g}$ ）を右側の歯列て咀謝 させたときの, 6 被検咀骝箭（左右側の咬等浅部中央部, 側頭筋前部拈よび側頭筋後部）における活動電位を表面 電極（日本光電工業株式会社製 NE-223S，電極間距離 $10 \mathrm{~mm}$ ) によって導出し, ポリクラフ（日本光電工業株 式会社製 RM-85) のインク書きオシロクララ（日本光 電工業株式会社製 WI-387G）打よびデータレコーダー （ソニー株式会社製 DFR-4915）飞記録した（図 1，2）.

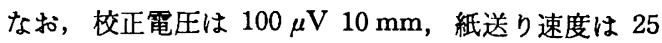

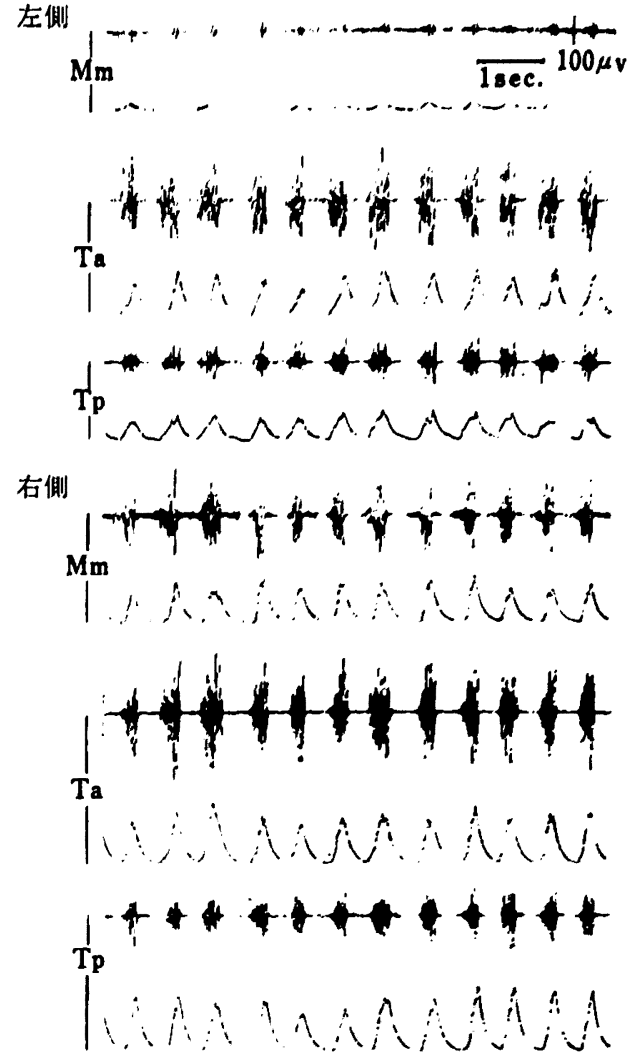

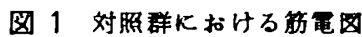
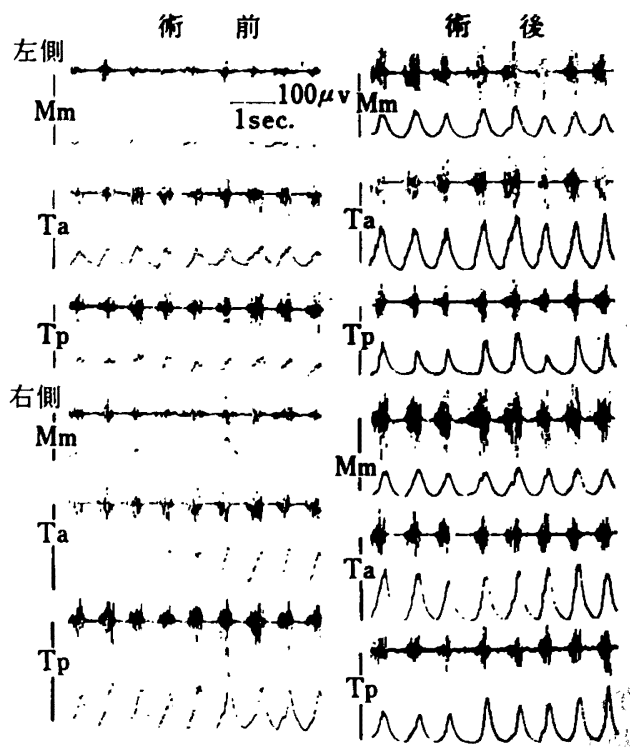

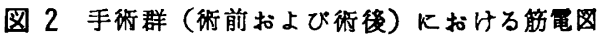




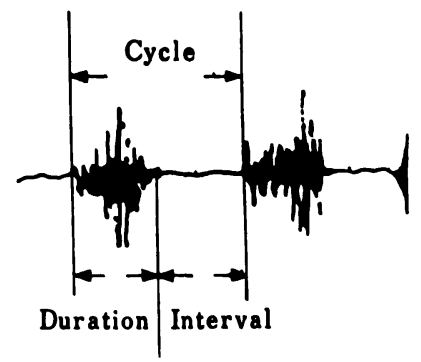

图 3 阻特リズムの計湘法（Duration: 故再 持繶時間，Interval：故電用隔，Cycle time： 1 ストローク時間)

$\mathrm{mm} / \mathrm{sec}$ とした.

2) 記録時期

手術群においては，術前（馣正処置前すなわち手術前 約 1 年) と術後（手術後約 1 年, すなわち智正処圈䅂了 後）とに記録した。

なお，対照群においては，㲹録時期は任意とした。

3）筋電図の分析

咀嘈させたチューインガムが㜞らかくなってからの 6 ストローク目（それまでの 5 ストロークは除外）から25 ストローク目までの20ストロークに扰ける burst（筋活 動）を対象として，そのリズムおよび burst 当りの筋活 動量を計測した。

a) 咀噃リズムの测定

咀哷リズムは咀㗖側における側頭筋前部を代表 ${ }^{41,42)}$ と して，オシログラフ上の原波形から放電持続時間（Duration, 活動電位の始まりから終了までの時間), 放電間 隔 (Interval, 活動電位の終了から次の活動電位の始ま りまでの時間) および1ストローク時間 (Cycle time, 活動電位の始まりから次の活動電位の始まりまでであ り，Duration と Interval を加えたもの）を測定し（図 3), Cycle time における Duration の占める割合を計 算した。

\section{b）筋活動量の算出}

筋活動量は六車 $(1965)^{41)}$ および橋本 (1969) 42)の方法 により記録した積分筋電困（図 1，2）の burst 当りの 波形につき面積計算を行って $\mathrm{mm}^{2}$ の単位で, 6 被検筋 の総活動量ならびに咀嚼側および対側の 3 被㭘筋の総活 動量を算出した。なお，用いた積分計は日本光電工業株 式会社製, RFJ-5 である.

c) 咀婙リズム怙よび筋活動量の統計処理

手街群および対照群における咀噃りズムおよび筋活動 量についての各測定値およびその母平均（1ストローク の値) の信頼限界を信頼度 $95 \%$ で求め, 平均値の差の有 意性を $\mathrm{t}$ 検定によって検定した。

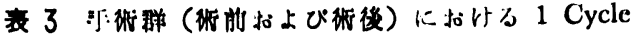

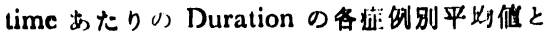
その倡賴限界

(sec.)

\begin{tabular}{|c|c|c|c|c|}
\hline \multicolumn{3}{|c|}{ 症例番吕 } & \multirow{2}{*}{$\frac{\text { 平均优 }}{0.41}$} & \multirow{2}{*}{$\frac{\text { 倍闻限界 }}{0.374 \leqq \mathrm{~m} \leqq 0.452}$} \\
\hline & 堔 & 放 & & \\
\hline & 政 & 後 & 0.28 & $0.248 \cong \mathrm{m}<0.312$ \\
\hline 2 & 行 & 的 & 0.66 & $0.612 \leqq \mathrm{~m} \leqq 0.708$ \\
\hline 2. & 術 & 啳 & 0.45 & $0.415 \leqq m \leqq 0.485$ \\
\hline 3 & 堔 & 的 & 0.47 & $0.439 \leqq \mathrm{~m} \leqq 0.501$ \\
\hline 3. & 许 & 後 & 0.43 & $0.408 \leqq \mathrm{~m} \leqq 0.452$ \\
\hline 1 & 行 & 的 & 0.65 & $0.621 \leqq \mathrm{~m} \leqq 0.679$ \\
\hline 4. & 政 & 啳 & 0.36 & $0.339 \leqq \mathrm{~m}-0.381$ \\
\hline 5 & 杽 & 前 & 0.63 & $0.599 \leqq m \leqq 0.661$ \\
\hline J. & 堔 & 後 & 0.51 & $0.486 \leqq \mathrm{~m} \leqq 0.534$ \\
\hline 6 & 柠 & 前 & 0.76 & $0.709 \leqq \mathrm{~m} \leqq 0.811$ \\
\hline o. & 堔 & 後 & 0.46 & $0.437 \leqq m \leqq 0.483$ \\
\hline 7 & 術 & 前 & 0.50 & $0.459 \leqq m \leqq 0.541$ \\
\hline r. & 㭪 & 後 & 0.36 & $0.333 \leqq \mathrm{~m} \leqq 0.387$ \\
\hline 8 & 科 & 前 & 0.43 & $0.398 \leqq \mathrm{~m} \leqq 0.462$ \\
\hline 0. & 嫲 & 後 & 0.39 & $0.360 \leqq \mathrm{~m} \leqq 0.420$ \\
\hline 0 & 御 & 前 & 0.52 & $0.435 \leqq \mathrm{~m} \leqq 0.605$ \\
\hline 9. & 彿 & 後 & 0.46 & $0.387 \leqq \mathrm{~m} \leqq 0.533$ \\
\hline 10 & 術 & 前 & 0.42 & $0.398 \leqq \mathrm{~m} \leqq 0.442$ \\
\hline & 继 & 後 & 0.27 & $0.257 \leqq \mathrm{~m} \leqq 0.283$ \\
\hline
\end{tabular}

表 4 対照群における 1 Cycle time あたりの Duration の各被㭘者別平均値とその信 頼限界

(sec.)

\begin{tabular}{c|c|c}
\hline 対照群 & 平均値 & 信頪限界 \\
\hline $\mathrm{A}$ & 0.22 & $0.206 \leqq \mathrm{~m} \leqq 0.234$ \\
$\mathrm{~B}$ & 0.34 & $0.312 \leqq \mathrm{~m} \leqq 0.368$ \\
$\mathrm{C}$ & 0.24 & $0.225 \leqq \mathrm{~m} \leqq 0.255$ \\
$\mathrm{D}$ & 0.35 & $0.338 \leqq \mathrm{~m} \leqq 0.362$ \\
$\mathrm{E}$ & 0.30 & $0.286 \leqq \mathrm{~m} \leqq 0.314$ \\
\hline
\end{tabular}

\section{研 究 結 果}

\section{1. 咀跍リズム}

1) Duration

a ）手術群の各症例の術前と術後ならびに対照群の各 被検者について湘定した 1 Cycle time あたりの Duration (20ストロークの平均値) およびその信頼限界（表 3，4，图 4）から，各症例別に術前と術後との Durationを比較すると，術後には全症例において Duration は短縮している。特に, 症例 $1,2,4,5,6,7$ 拧 よび10の 7 症例においては, 術前と術後の差は有意であ った。ただし，他の 3 症例においては有意差は認められ 


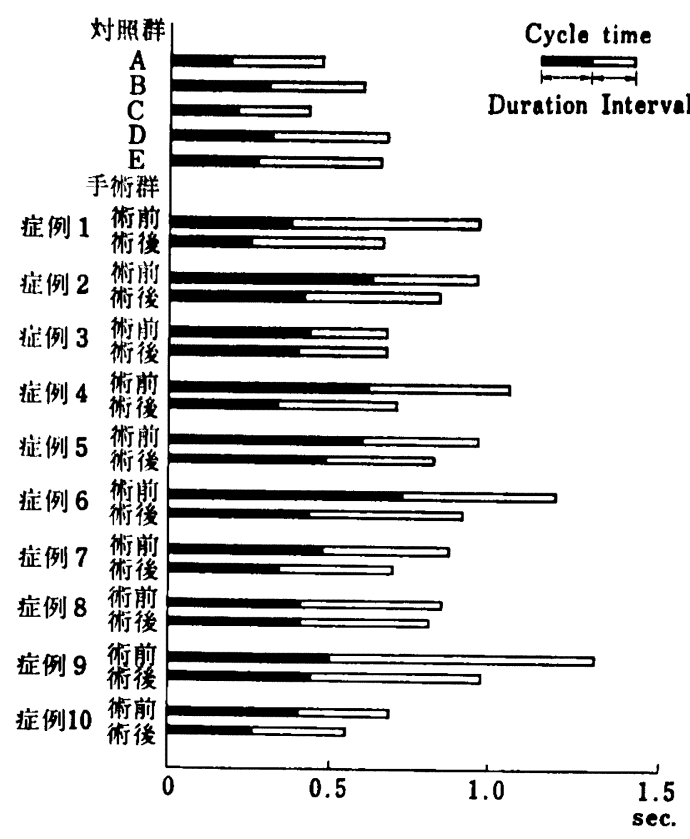

图 4 対將群および手術群（㭪前および術後）にお ける Duration, Interval おょよび Cycle time の各被检者別平均値

なかった。

b）手術群の全证例と対照群の全被検者との 1 Cycle time あたりの Duration の平均値およびその信頼限界 （表 5, 図 5）から，Duration は術後では術前よりる有 意に短くなっており，また，対照群と術前との問にも有 意差が認められたが，しかし，刘照群と術後との間には 有意差は認めなかった。

2) Interval

a) 手術群の各症例の術前と術後ならびに対照群の各 被検者について測定した 1 Cycle time あたりの Inter$\operatorname{val}(20$ ストロークの平均値)およびその信頼限界（表 6 ， 7. 图 4）から, 各症例别に術前と術後との Interval を 比較すると, 症例 $1 ， 4 ， 5$ および 9 の 4 症例において は，術後に Interval の有意な短縮が認められた。しか し，他の症例においては有意差は認められなかった。

b）手術群の全症例と対照群の全被検者との 1 Cycle time あたりの Interval については, その平均值および 平均值の信頼限界（表 5, 図 5) から, 術前と術後, 対 照群と術前および対照群と術後との間には有意の差は認 められなかった。

3) Cycle time

a ）手術群の各症例の術前と術後ならびに対照群の各 被検者について測定した Cycle time (20ストロークの 平均値) 扐よびその信頼限界（表 8，9，図4）から， 各症例別に術前と術後の Cycle time を比較すると, 症

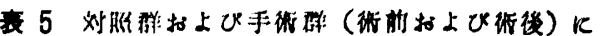
to ける Duration, Interval 括よひ Cycle

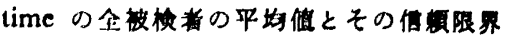

(sec.)

\begin{tabular}{|c|c|c|c|c|}
\hline & & & 平均何 & 信買限界 \\
\hline Duration & 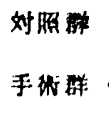 & 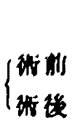 & $\begin{array}{l}0.29 \\
0.54 \\
0.40\end{array}$ & $\begin{array}{l}0.218 \mathrm{~m} \leqq 0.362 \\
0.456 \leqq \mathrm{~m} \leqq 0.624 \\
0.358 \leqq \mathrm{~m} \leqq 0.442\end{array}$ \\
\hline Interval & $\begin{array}{l}\text { 対胎群 } \\
\text { 決你群 }\end{array}$ & $\left\{\begin{array}{l}\text { 術的 } \\
\text { 術啳 }\end{array}\right.$ & $\begin{array}{l}0.32 \\
0.45 \\
0.39\end{array}$ & $\begin{array}{l}0.239 \leqq m \leqq 0.401 \\
0.326 \leqq m \leqq 0.574 \\
0.340 \leqq m \leqq 0.440\end{array}$ \\
\hline $\begin{array}{l}\text { Cycle } \\
\text { time }\end{array}$ & $\begin{array}{l}\text { 対䏡群 } \\
\text { 手菜群 }\end{array}$ & $\left\{\begin{array}{l}\text { 衙时 } \\
\text { 急侵 }\end{array}\right.$ & $\begin{array}{l}0.61 \\
0.99 \\
0.79\end{array}$ & $\begin{array}{l}0.482 \leqq m \leqq 0.738 \\
0.847 \leqq m \leqq 1.133 \\
0.698 \leqq m \leqq 0.882\end{array}$ \\
\hline
\end{tabular}

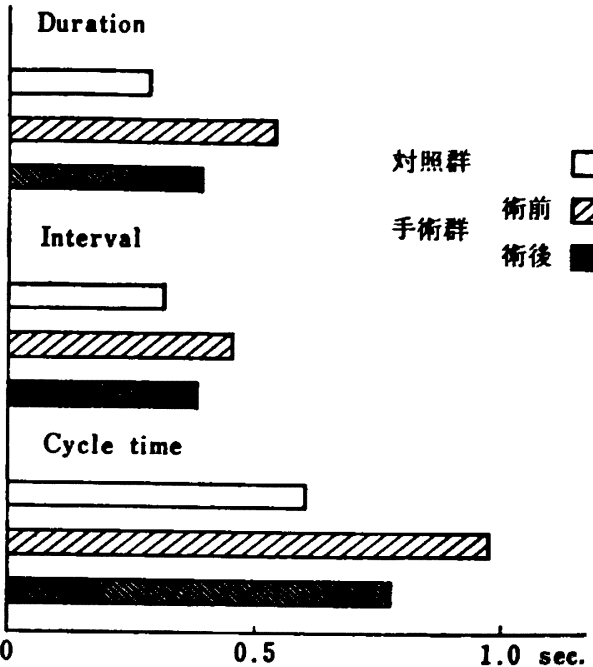

图 5 対炤群およひ手術群（郝前およひ㭪後）に おける Duration, Interval およひ Cycle time の全菠检者の平均值

例 3 を除く他の 9 应例において街後に Cycle time の短 樎を認めた，特に，症例 $1,2,4,5,6,7,9$ および10 の 8 症例においては, 術前と術後との差は梳計的に有意 であった。

b）手術群の全症例と対照群の全被佮者との Cycle time の平均値およびその倞頼限界（表 5，図5）とか ら, Cycle time は対照群と術前との間には有意差は認 められたが，術前と術後との間および対照群と術後との 間では有意の差を怹めなかった。

4) Cycle time における Duration の占める割合

a ）手術群の各症例の術前と術後ならびに対照群の各 被検者についての Cycle time における Duration の占 


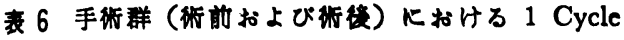
time あたりの Interval の各症侧则平场倾と その作頼限界

(sec.)

\begin{tabular}{|c|c|c|c|c|}
\hline \multicolumn{3}{|c|}{ 症例番号 } & \multirow{2}{*}{$\frac{\text { 平均伹 }}{0.59}$} & \multirow{2}{*}{$\frac{\text { 伯頼限界 }}{0.553 \leqq \mathrm{~m} \leqq 0.630}$} \\
\hline & 徉 & 前 & & \\
\hline 1. & 得 & 徏 & 0.43 & $0.389 \leqq m \leqq 0.451$ \\
\hline \multirow{2}{*}{2.} & 䛧 & 前 & 0.34 & $0.288 \leqq m \leqq 0.392$ \\
\hline & 政 & 後 & 0.42 & $0.378 \leqq m \leqq 0.464$ \\
\hline \multirow{2}{*}{3.} & 術 & 前 & 0.24 & $0.199 \leqq m \leqq 0.281$ \\
\hline & 堔 & 後 & 0.28 & $0.256 \leqq m \leqq 0.304$ \\
\hline \multirow{2}{*}{4.} & 䛧 & 前 & 0.45 & $0.411 \leqq \mathrm{~m} \leqq 0.489$ \\
\hline & 政 & 徏 & 0.38 & $0.356 \leqq m \leqq 0.404$ \\
\hline \multirow{2}{*}{5.} & 堔 & 前 & 0.37 & $0.331 \fallingdotseq \mathrm{m} \leqq 0.409$ \\
\hline & 继 & 媵 & 0.30 & $0.273 \leqq m \leqq 0.327$ \\
\hline \multirow{2}{*}{6.} & 秃 & 前 & 0.49 & $0.350 \leqq m \leqq 0.630$ \\
\hline & 堔 & 啳 & 0.49 & $0.446 \leqq \mathrm{~m} \leqq 0.514$ \\
\hline \multirow{2}{*}{7.} & 堔 & 前 & 0.40 & $0.347 \leqq m \leqq 0.453$ \\
\hline & 㭪 & 挠 & 0.36 & $0.335 \leqq m \leqq 0.385$ \\
\hline \multirow{2}{*}{8.} & 政 & 前 & 0.45 & $0.407 \leqq m \leqq 0.493$ \\
\hline & 術 & 媵 & 0.45 & $0.417 \leqq m \leqq 0.483$ \\
\hline & 術 & 前 & 0.85 & $0.757 \leqq m \leqq 0.943$ \\
\hline & 街 & 後 & 0.54 & $0.502 \leqq \mathrm{~m} \leqq 0.578$ \\
\hline \multirow{2}{*}{10.} & 继 & 前 & 0.29 & $0.253 \leqq \mathrm{~m} \leqq 0.327$ \\
\hline & & 後 & 0.30 & $0.286 \leqq \mathrm{~m} \leqq 0.314$ \\
\hline
\end{tabular}

表 7 奶炤群における 1 Cycle time おたりの Interval の各被楅者別平均値とその信頼 限界

(sec.)

\begin{tabular}{c|c|c}
\hline 対照群 & 平均値 & 信頼限界 \\
\hline $\mathrm{A}$ & 0.29 & $0.260 \leqq \mathrm{~m} \leqq 0.320$ \\
$\mathrm{~B}$ & 0.30 & $0.277 \leqq \mathrm{~m} \leqq 0.323$ \\
$\mathrm{C}$ & 0.23 & $0.213 \leqq \mathrm{~m} \leqq 0.247$ \\
$\mathrm{D}$ & 0.37 & $0.337 \leqq \mathrm{~m} \leqq 0.403$ \\
$\mathrm{E}$ & 0.39 & $0.365 \leqq \mathrm{~m} \leqq 0.415$ \\
\hline
\end{tabular}

める割合 (20ストロークの平均値) およびその信頼限界 (表10，11）から，症例 $1 ， 2 ， 4 ， 6 ， 7$ およ゙ 10 の 6 症例において, Cycle time における Duration の占 める割合は，術後では有意に小さくなることが明らかに なったか，その他の症例においては有意差は認められな かった.

b）手術群の全症例と対照群の全被検者の Cycle time における Duration の占める割合は, 術前と術後との間 および対照群と術後との間には有意差は認められなかっ たが，対照群と術前との間では有意の差が認められた。

5) 手衍群および対照群における各被検者の咀㗖りズ ムの比較
衰 8 丁行群（行能打よび你後）におけるCycle

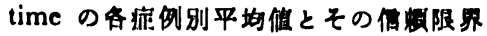

(sec.)

\begin{tabular}{|c|c|c|c|c|}
\hline \multicolumn{3}{|c|}{ 症例番舟 } & 平均健 & 伯赖煺界 \\
\hline \multirow{2}{*}{1.} & 行 & 施 & 1.00 & $0.949 \leqq m \leqq 1.061$ \\
\hline & 行 & 倦 & 0.71 & $0.666 \leqq m \leqq 0.734$ \\
\hline \multirow{2}{*}{2.} & 堔 & 斺 & 1.00 & $0.948 m=1.052$ \\
\hline & 堔 & 啳 & 0.87 & $0.830 \leqq m \leqq 0.910$ \\
\hline \multirow{2}{*}{3.} & 行 & 前 & 0.71 & $0.661 \leqq m \leqq 0.759$ \\
\hline & 行 & 啳 & 0.71 & $0.443 \leqq m \leqq 0.977$ \\
\hline \multirow{2}{*}{4.} & 行 & 前 & 1.10 & $1.066 \leqq m \leqq 1.134$ \\
\hline & 㭪 & 後 & 0.74 & $0.771 \leqq m-0.769$ \\
\hline \multirow{2}{*}{5.} & 政 & 勭 & 1.00 & $0.932 \leqq m \leqq 1.068$ \\
\hline & 政 & 啳 & 0.81 & $0.767 \leqq m \leqq 0.853$ \\
\hline \multirow{2}{*}{6.} & 堔 & 前 & 1.25 & $1.180 \leqq \mathrm{~m} \leqq 1.342$ \\
\hline & 政 & 後 & 0.95 & $0.911 \leqq \mathrm{~m} \leqq 0.989$ \\
\hline \multirow{2}{*}{7.} & 政 & 前 & 0.90 & $0.832 \leqq \mathrm{~m} \leqq 0.968$ \\
\hline & 㣭 & 後 & 0.72 & $0.690 \leqq m \leqq 0.750$ \\
\hline \multirow{2}{*}{8.} & 深 & 前 & 0.88 & $0.875 \leqq m \leqq 0.885$ \\
\hline & 街 & 後 & 0.84 & $0.800 \leqq m=0.880$ \\
\hline \multirow{2}{*}{9.} & 術 & 前 & 1.37 & $1.254 \leqq \mathrm{~m} \leqq 1.486$ \\
\hline & 行 & 後 & 1.00 & $0.909 \leqq \mathrm{~m} \leqq 1.091$ \\
\hline \multirow{2}{*}{10.} & 術 & 前 & 0.71 & $0.666 \leqq \mathrm{~m} \leqq 0.754$ \\
\hline & 行 & 後 & 0.57 & $0.555 \leqq \mathrm{~m} \leqq 0.584$ \\
\hline
\end{tabular}

表 9 対照群における Cycle time の各被㭘者別 平均値とその伊頼限界

(sec.)

\begin{tabular}{c|c|c}
\hline 対炤群 & 平均值 & 信頼限界 \\
\hline A & 0.51 & $0.489 \leqq \mathrm{~m} \leqq 0.531$ \\
B & 0.64 & $0.606 \leqq \mathrm{~m} \leqq 0.674$ \\
C & 0.47 & $0.451 \leqq \mathrm{~m} \leqq 0.489$ \\
D & 0.72 & $0.682 \leqq \mathrm{~m} \leqq 0.758$ \\
E & 0.69 & $0.669 \leqq \mathrm{~m} \leqq 0.711$ \\
\hline
\end{tabular}

手術群（術前および術後）および対照群のそれぞれの 数例について，チューインガム20回咀㛵時の, 各ストロ ークごとの Duration, Interval および Cycle time を ブロットして（图6～8）比較すると，症例 8 において は術前の各ストロークにおける Duration, Interval およ び Cycle time の変動は大きいか，術後では小さくな り，一定のリズムに近ついている. この傾向はその程度 に差異はあるが, 症例 4 においても同様に認められる.

これに対して，対照群においてはもちろん Duration, Interval および Cycle time の変動が小さくて, しかも 安定している. 


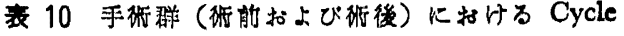
time における Duration の占める㔂合の

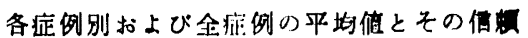
限界

(\%)

\begin{tabular}{|c|c|c|c|c|}
\hline \multicolumn{3}{|c|}{ 症例番号 } & 平均值 & 倡㛲限界 \\
\hline \multirow{2}{*}{1.} & 術 & 前 & 40.4 & $38.4 \leqq m \leqq 42.4$ \\
\hline & 唖 & 嵝 & 39.9 & $36.1: \mathrm{m} \leqq 36.1$ \\
\hline \multirow{2}{*}{2.} & 埱 & 前 & 66.2 & $62.0 \leqq m \leqq 70.4$ \\
\hline & 衡 & 後 & 52.1 & $47.5: \mathrm{m}: 55.7$ \\
\hline \multirow{2}{*}{3.} & 御 & 的 & 65.8 & $59.8 \leqq \mathrm{~m} \leqq 71.8$ \\
\hline & 呲 & 後 & 61.8 & $57.5 \leqq \mathrm{~m} \leqq 66.0$ \\
\hline \multirow{2}{*}{4.} & 继 & 前 & 59.4 & $56.3 \leqq \mathrm{~m} \leqq 62.5$ \\
\hline & 御 & 後 & 48. 3 & $46.4 \leqq m \leqq 50.2$ \\
\hline \multirow{2}{*}{5.} & 術 & 前 & 46.9 & $44.8 \leqq m \leqq 49.0$ \\
\hline & 術 & 後 & 62.5 & $59.1 \leqq m \leqq 65.9$ \\
\hline \multirow{2}{*}{6.} & 䇛 & 前 & 60.5 & $58.5 \leqq m \leqq 62.5$ \\
\hline & 術 & 後 & 48.9 & $46.6 \leqq \mathrm{~m} \leqq 51.2$ \\
\hline \multirow{2}{*}{7.} & 術 & 前 & 56.0 & $55.7 \leqq \mathrm{~m} \leqq 56.2$ \\
\hline & 術 & 後 & 50.4 & $47.5 \leqq m \leqq 53.2$ \\
\hline \multirow{2}{*}{8.} & 㭪 & 前 & 48. 7 & $44.7 \leqq \mathrm{~m} \leqq 52.7$ \\
\hline & 衡 & 後 & 45.9 & $44.4 \leqq \mathrm{~m} \leqq 47.4$ \\
\hline \multirow{2}{*}{9.} & 政 & 前 & 37.5 & $33.4 \leqq m \leqq 41.6$ \\
\hline & 術 & 後 & 44.7 & $41.0 \leqq m \leqq 48.3$ \\
\hline \multirow{2}{*}{10.} & 術 & 前 & 58.9 & $50.7 \leqq \mathrm{~m} \leqq 70.0$ \\
\hline & 㣥 & 後 & 47.8 & $46.3 \leqq m \leqq 49.3$ \\
\hline \multirow{2}{*}{ 平均值 } & 标 & 前 & 54.0 & $50.4 \leqq m \leqq 57.9$ \\
\hline & 政 & 後 & 50.2 & $47.2 \leqq \mathrm{~m} \leqq 53.1$ \\
\hline
\end{tabular}

表 11 対照群における Cycle time における Duration の占める割合の各被检者別 平均値とその信頼限界

(\%)

\begin{tabular}{c|c|c}
\hline 対炤群 & 平均値 & 信頼限界 \\
\hline $\mathrm{A}$ & 39.2 & $35.9 \leqq \mathrm{~m} \leqq 42.1$ \\
$\mathrm{~B}$ & 57.4 & $53.7 \leqq \mathrm{~m} \leqq 61.2$ \\
$\mathrm{C}$ & 50.1 & $46.1 \leqq \mathrm{~m} \leqq 52.9$ \\
$\mathrm{D}$ & 43.4 & $40.3 \leqq \mathrm{~m} \leqq 46.3$ \\
$\mathrm{E}$ & 43.8 & $41.6 \leqq \mathrm{~m} \leqq 46.0$ \\
\hline 平均値 & 46.8 & $43.5 \leqq \mathrm{~m} \leqq 49.7$ \\
\hline
\end{tabular}

\section{2. 筋活動量}

1） 6 被検筋（左右側の咬筋，側頭筋前部および側頭 筋後部) の総活動量

a) 手術群の各症例の術前と術後ならびに対照群の各 被検者について算出した 1 ストロークあたりの 6 被検筋 の活動量の総利（20ストロークの平均値）およびその信 頼限界（表12，13）から，どの症例において子術後には

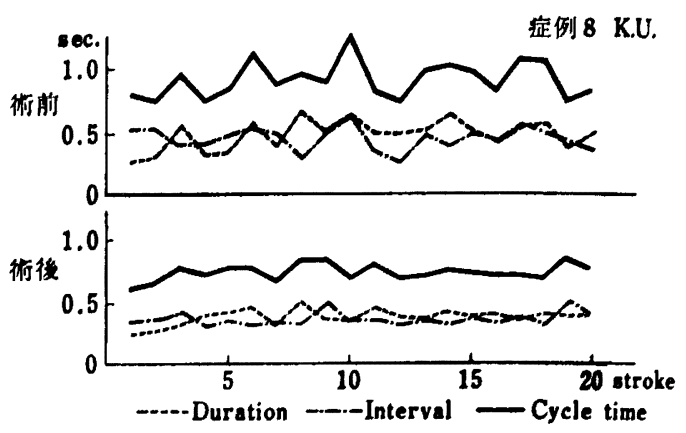

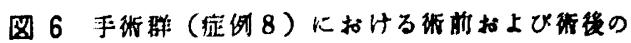
朋軥リズ

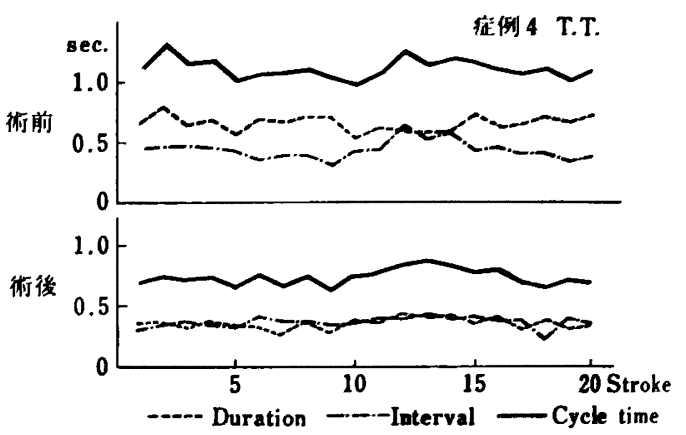

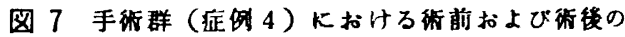
咀时リズム

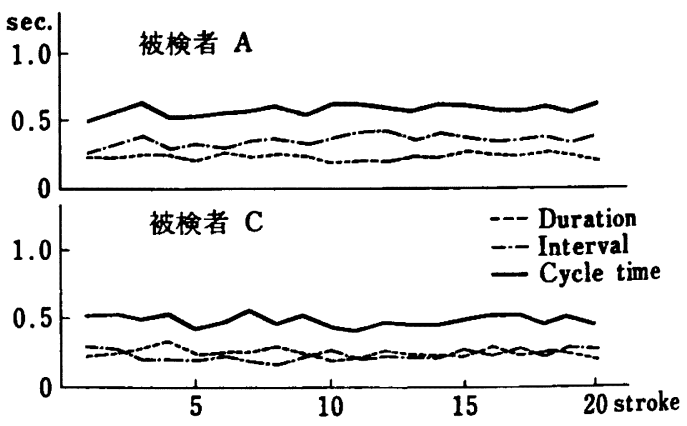

图 8 対照群（被检者Aおよび被检者B）における 咀嘌リメム

6 被検筋の総活動量が增大していることが明らかになっ た. 特に症例 5 を除く 9 症例に执いては, 術前と術後と の差は統計的に有意であった。

b）手術群の全症例と対照群との全被検者の 1 ストロ 一クあたりの 6 被検筋の総活動量の平均値については, 術前と術後との間, また手術群と対照群との間には䋽計 的に有意差は認められなかった（表 14）。 
表 12 手原群（原前および行徏）における1スト ロークおたりの 6 被检筋の総活䣦昷り各症 例别平均值およびその作烦限界 $\left(\mathrm{mm}^{8}\right)$

\begin{tabular}{|c|c|c|c|c|c|}
\hline \multicolumn{3}{|c|}{ 症例番号 } & \multirow{2}{*}{$\frac{\text { 平物值 }}{585}$} & \multicolumn{2}{|l|}{ 倩顆限界 } \\
\hline \multirow{2}{*}{1.} & 得 & 前 & & $517.1 \leqq \mathrm{~m} \leqq$ & 652.1 \\
\hline & 很 & 後 & 751 & 708. $8 \leqq m \leqq$ & 793. 2 \\
\hline \multirow{2}{*}{2.} & 術 & 前 & 369 & $325.9 \leqq \mathrm{~m} \leqq$ & 412.1 \\
\hline & 術 & 後 & 609 & 563. $8 \leqq m \leqq$ & 654.2 \\
\hline \multirow{2}{*}{3.} & 㣭 & 前 & 301 & 270.1 $1 \mathrm{~m} \leqq$ & 331.9 \\
\hline & 继 & 媵 & 457 & 419. $6: \mathrm{m} \leqq$ & 494. 4 \\
\hline \multirow{2}{*}{4.} & 得 & 前 & 337 & $308.6 \leq \mathrm{m} \leqq$ & 365.4 \\
\hline & 得 & 媵 & 476 & $436.9 \leqq m \leqq$ & 515.1 \\
\hline \multirow{2}{*}{5.} & 術 & 前 & 1,234 & \multicolumn{2}{|c|}{$1,094.9 \leqq m \leqq 1,373.1$} \\
\hline & 㭪 & 啳 & 1,423 & \multicolumn{2}{|c|}{$1,349.7 \leqq m \leqq 1,496.3$} \\
\hline \multirow{2}{*}{6.} & 耖 & 前 & 481 & 394. 9 : $\mathrm{m} \leqq$ & 441.1 \\
\hline & 政 & 後 & 566 & $532.0 \leqq \mathrm{~m} \leqq$ & 600.0 \\
\hline \multirow{2}{*}{7.} & 㭪 & 前 & 180 & 164. $9 \leqq \mathrm{~m} \leqq$ & 195.1 \\
\hline & 術 & 後 & 322 & $277.2 \leqq \mathrm{~m} \leqq$ & 366.8 \\
\hline \multirow{2}{*}{8.} & 䛧 & 前 & 363 & $333.2 \leqq \mathrm{~m} \leqq$ & 392.8 \\
\hline & 術 & 後 & 505 & 463. $5 \leqq \mathrm{~m} \leqq$ & 546.5 \\
\hline & 術 & 前 & 102 & 88. $1 \leqq \mathrm{~m} \leqq$ & 115.9 \\
\hline & 術 & 啳 & 348 & $314.1 \leqq m \leqq$ & 381.9 \\
\hline \multirow{2}{*}{10.} & 術 & 前 & 373 & $351.0 \leqq \mathrm{~m} \leqq$ & 395.0 \\
\hline & 術 & 後 & 532 & $479.6 \leqq \mathrm{~m} \leqq$ & 566.4 \\
\hline
\end{tabular}

表 13 対照群における1ストロークおたりの 6 被 検筋の総活動量の各被检者別平均値とその 信頼限界

$\left(\mathrm{mm}^{2}\right)$

\begin{tabular}{c|c|c}
\hline 対炤群 & 平均値 & 信頼限界 \\
\hline $\mathrm{A}$ & 598 & $522.8 \leqq \mathrm{~m} \leqq 674.2$ \\
$\mathrm{~B}$ & 607 & $518.5 \leqq \mathrm{~m} \leqq 695.5$ \\
$\mathrm{C}$ & 615 & $561.4 \leqq \mathrm{~m} \leqq 668.6$ \\
$\mathrm{D}$ & 903 & $839.2 \leqq \mathrm{~m} \leqq 966.8$ \\
$\mathrm{E}$ & 351 & $310.8 \leqq \mathrm{~m} \leqq 391.2$ \\
\hline
\end{tabular}

表 14 対炤群および手術群（抔前および㣝後）に おける1ストロークおたりの 6 被槐筋の総 活動量の全被検者の平均值とその信頼限界

$\left(\mathrm{mm}^{2}\right)$

\begin{tabular}{|c|c|c|}
\hline & 平均値 & 信頼限界 \\
\hline 対照群 & 614 & $371.2 \leqq \mathrm{~m} \leqq 856.8$ \\
\hline (很前 & 426 & $210.0 \leqq \mathrm{~m} \leqq 642.0$ \\
\hline 手訹群 $\{$ 術後 & 599 & $373.7 \leqq \mathrm{~m} \leqq 824.1$ \\
\hline
\end{tabular}

2) 咀哷側の 3 被検筋（右側の咬筋, 側頭筋前部およ び側頭笳後部) の総活動量

a ) 手術群の各症例の術前と術後ならびに対照群の各

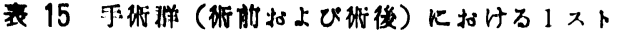

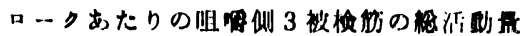

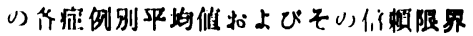

$\left(\mathrm{mm}^{2}\right)$

\begin{tabular}{|c|c|c|c|c|}
\hline \multicolumn{3}{|c|}{ 杖侧音号 } & 均们 & 们颗限界 \\
\hline & 術 & 时 & 319 & $267.7 \leqq m \leqq 370.3$ \\
\hline & 悑 & 後 & 399 & $375.4 \leqq \mathrm{~m} \leqq 422.6$ \\
\hline \multirow{2}{*}{2.} & 術 & iii! & 318 & $266.3^{-} \mathrm{m} \leqq 369.7$ \\
\hline & 術 & 媵 & 507 & $462.8=m=551.2$ \\
\hline \multirow{2}{*}{3.} & 術 & 解 & 225 & $186.9=m<263.1$ \\
\hline & 訹 & 後 & 346 & 303. $0 \circ-m \cong 379.0$ \\
\hline \multirow{2}{*}{4.} & 踭 & 前 & 203 & $186.5 . \mathrm{m} \cdot 219.5$ \\
\hline & 㭪 & 後 & 306 & 279. $7 \subseteq \mathrm{m} \leqq 332.3$ \\
\hline \multirow{2}{*}{5.} & 政 & 前 & 784 & $716.5 \leqq \mathrm{~m} \leqq 851.5$ \\
\hline & 㭪 & 後 & 873 & $824.2 \leqq \mathrm{~m} \leqq 921.8$ \\
\hline \multirow{2}{*}{6.} & 政 & 前 & 218 & $195.5 \leqq m \leqq 240.5$ \\
\hline & 術 & 後 & 354 & $320.0 \leqq \mathrm{~m} \leqq 388.0$ \\
\hline \multirow{2}{*}{7.} & 掂 & 前 & 93 & $83.0 \leqq \mathrm{~m} \leqq 103.0$ \\
\hline & 得 & 後 & 198 & $154.2 \leqq \mathrm{~m}=241.8$ \\
\hline \multirow{2}{*}{8.} & 㭪 & 前 & 213 & $196.1 \leqq \mathrm{~m} \leqq 229.9$ \\
\hline & 称 & 後 & 318 & $283.5 \mathrm{~m} \leqq 352.5$ \\
\hline \multirow{2}{*}{9.} & 術 & 前 & 54 & $22.4-\mathrm{m} \leqq 85.6$ \\
\hline & 行 & 後 & 215 & 193. $9 \leqq \mathrm{~m} \leqq 236.1$ \\
\hline \multirow{2}{*}{10.} & 征 & 前 & 239 & $217.5 \leqq \mathrm{~m} \leqq 260.5$ \\
\hline & & 後 & 312 & $282.3 \simeq \mathrm{m} \leqq 341.7$ \\
\hline
\end{tabular}

表 16 対照群における1ストロークおたりの 3 被 模筋の総活動量の各被検者別平均値とその 信頼限界 $\left(\mathrm{mm}^{2}\right)$

\begin{tabular}{c|c|c}
\hline 対炤群 & 平均値 & 信頼限界 \\
\hline A & 411 & $338.6 \leqq \mathrm{~m} \leqq 483.4$ \\
B & 396 & $320.8 \leqq \mathrm{~m} \leqq 471.2$ \\
C & 366 & $313.4 \leqq \mathrm{~m} \leqq 418.6$ \\
D & 581 & $459.2 \leqq \mathrm{~m} \leqq 702.8$ \\
E & 189 & $151.5 \leqq \mathrm{~m} \leqq 226.5$ \\
\hline
\end{tabular}

被検者について算出した 1 ストロークあたりの咀㗖侧の 3 被検筋の活動量の総和 (20ストロークの平均値) およ びその信頼限界（表15，16）から，どの症例においてむ 術後には咀畄側の 3 被検筋の総活動量は増大しているこ とが判明した。特に, 症例 $1,2,3,4,6,7$, 8, 9 および10の 9 症例においては術前と術後との差は 統計的に有意であった.

b) 手術群の全症例と対照群との全被検者の 1 スト口 ークあたりの咀嚼側の 3 被検筋の総活動量の平均値につ いては, 術前と術後との間, また手術群と対照群との間 には統計的に有意差は認められなかった（表 17）. 


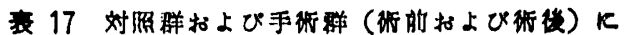
おける1ストロークあたりの明㧹侧および

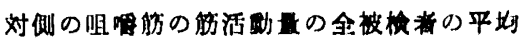
值とその传煩限界

$\left(\mathrm{mm}^{2}\right)$

\begin{tabular}{|c|c|c|c|c|}
\hline & & & 平均值 & 你頪限界 \\
\hline \multirow[t]{3}{*}{ 咀㖟側 } & \multicolumn{2}{|l|}{ 対周群 } & 390 & $216.7 \leqq m \leqq 563.3$ \\
\hline & \multirow{2}{*}{ 手菜群 } & (侮徆 & 267 & $123.9 \leqq m \leqq 410.1$ \\
\hline & & 娒後 & 384 & $267.3 \leqq \mathrm{~m} \leqq 498.7$ \\
\hline \multirow[t]{3}{*}{ 対 侧 } & 奶炤群 & & 220 & $148.5=m-303.5$ \\
\hline & \multirow{2}{*}{ 手御群 } & 旡前 & 160 & $72.3 \leqq m \leqq 247.7$ \\
\hline & & 柨後 & 216 & $117.0 \leqq \mathrm{~m} \leqq 315.0$ \\
\hline
\end{tabular}

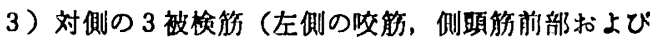
側頭筇啳部) の総活動量

a) 手術群の各症例の術前と術後ならびに対照群の各 被㭘者について算出した 1 ストロークあたりの対側の 3 被検能の活動量の総和（20ストロークの平均值）および その信頼限界（表18，19）から，との底例においてむ対 側の 3 被検筋の総活䡃量は增大していた，特に，症例 1，2，3，5，7．9および10の 7 症例においては術 前と術後との差は統計的に有意であった。

b）手術群の全症例と対照群との全被検者の 1 スト口 一クあたりの対側の 3 被検筋の総活禹量の平均值につい ては, 術前と術後との間，また，手術群と対照群との間 には統計的に有意差は認められなかった（表 17）。

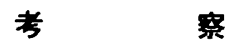

\section{1. 下額前突症の分類について}

外科的稪正手術を必要とする skeletal Class III malocclusion については, Sanborn (1955) ${ }^{43)}$ 《 4 群に, ま た花田ら (1975) ${ }^{27)}$ は 5 群に分けているが，木下・龍 田 ${ }^{15)}$ は 7 種の skeletal pattern および 2 種の denture pattern に分類している。

大阪荬科大学では，木下・龍田の分類によって下影前 㔖症の形態的特改を検討して，次のよらな特徽を有する もの, 寸なわち，1）下顯骨の過成長があって，主要症 状かＩ型 1 類， 4 類， 5 類および 7 類のどれかに属して 括り，2）上・下影骨の前後的位置がおのおの 1 S.D. を越えていて，ANB が 2 S.D. 以上あり，上下頻前媲 歯軸を 2 S.D. ずつ傾斜させても前菡被蓋関保が十分で なく，3) concave type (山型) の側貌を呈していて, 4) 咀唋および構音障害が認められるものを両側下影骨 骨体部部分切除短縮訹の適应症としている ${ }^{15}$.

そこで，本論文で報告した 10 症例を， skeletal Class III 分類（木下・龍田）によって分類すると, skeletal pattern では 1 類が 7 例, 4 類か 5 例, 5 類か 7 例, 6 類が 8 例, そして 7 類が 7 例であった。 すなわち，上頻

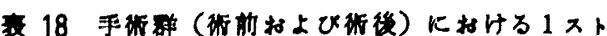

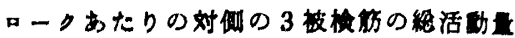
の各绽例则平好倠とその俉頼限界 ( $\left.\mathrm{mm}^{2}\right)$

\begin{tabular}{|c|c|c|c|}
\hline \multicolumn{2}{|c|}{ 痽例霜早 } & \multirow{2}{*}{$\frac{\text { 平均倾 }}{266}$} & \multirow{2}{*}{$\frac{\text { 伊貺限䍗 }}{240.0 \leqq m \leqq 292.0}$} \\
\hline & 部 & & \\
\hline 1. 质 & 後 & 352 & $313.8 \leqq \mathrm{~m} \leqq 390.2$ \\
\hline & 前 & 51 & $42.8 \leqq m \leqq 59.2$ \\
\hline 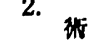 & 啳 & 102 & 88. $3 \leqq m \leqq 115.7$ \\
\hline & 前 & 76 & $64.0 \leqq m \leqq 88.0$ \\
\hline J. 政 & 啳 & 111 & $103.8 \leqq m \leqq 118.2$ \\
\hline 晸 & 的 & 134 & $109.4 \leqq m \leqq 158.6$ \\
\hline 4. 侕 & 後 & 170 & $150.6 \leqq m \leqq 189.4$ \\
\hline & 前 & 450 & $424.4 \leqq m \leqq 475.6$ \\
\hline D. 徙 & 後 & 550 & $508.1 \leqq m \leqq 591.9$ \\
\hline 6 埱 & 前 & 200 & $191.1 \leqq m \leqq 208.9$ \\
\hline b. 堔 & 後 & 212 & $197.5 \leqq m \leqq 226.5$ \\
\hline & 前 & 87 & $69.5 \leqq m \leqq 104.5$ \\
\hline 7 菜 & 啳 & 124 & $110.7 \leqq m \leqq 137.3$ \\
\hline 8 . 䡓 & 前 & 150 & 113. $3 \leqq \mathrm{~m} \leqq 186.7$ \\
\hline ○. 政 & 後 & 187 & $159.9 \leqq \mathrm{~m} \leqq 214.1$ \\
\hline 9 很 & 前 & 48 & $36.3 \leqq \mathrm{~m} \leqq 59.7$ \\
\hline 9. 術 & 後 & 133 & $111.9 \leqq \mathrm{~m} \leqq 154.1$ \\
\hline 10 . 继 & 前 & 134 & $120.8 \leqq m \leqq 147.2$ \\
\hline & 後 & 220 & $202.6 \leqq m \leqq 237.4$ \\
\hline
\end{tabular}

衣 19 対照群における1ストロークおたりの対㑑

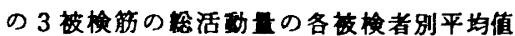
とその信頼限界 $\left(\mathbf{m m}^{2}\right)$

\begin{tabular}{c|c|c}
\hline 対炤群 & 平均値 & 信頼限界 \\
\hline $\mathrm{A}$ & 187 & $127.9 \leqq \mathrm{~m} \leqq 246.1$ \\
$\mathrm{~B}$ & 211 & $143.6 \leqq \mathrm{~m} \leqq 278.4$ \\
$\mathrm{C}$ & 249 & $186.3 \leqq \mathrm{~m} \leqq 311.7$ \\
$\mathrm{D}$ & 322 & $208.8 \leqq \mathrm{~m} \leqq 435.2$ \\
$\mathrm{E}$ & 162 & $116.6 \leqq \mathrm{~m} \leqq 207.4$ \\
\hline
\end{tabular}

骨が正常であって，下額骨の過成長によって下䫑枝およ び下穎角に異常を生じ，また田齿部の反対咬合を示する のが大多数を占めていた。

さらに, 10 症例中, 症例 3 は 1 類, 症例 7 は 7 類の及 であるか，他の 8 症例については 3 つ以上の症状を合併 している.

そして, denture pattern では, 1 類は 8 例，2類は

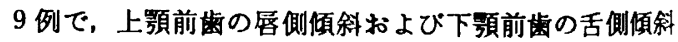
を認めたものが圧倒的に多かった。

\section{2. 下預前㔖症手術について}

下顥前突症患者を初めて外科的に 処置した Hullihen $(1849)^{1)}$ は，顔面および頙部の熱倁によって生した，開 


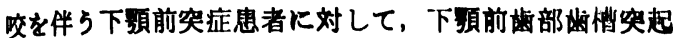
部を手衍的に後退させて，良好な結果を得たと報告して いる.

哂正治㞠によって下䫑前突症の咬合関係を変えること は可能であるが，下顥前突まで变えることはできないか ら，顔镍を改善するととすに咬合咸係をも変えることの できる治港法としては，手術を行らことが最通と考えら れるよらになり，さらにその術式を改良したり，抗生物 貝を併用したりすることによって手術操作そのるのおよ び徏後の感染の制御が容易となり，外科的知正法す進步 してきた.

そして，下預前突症手術のらち，下頻情骨体部におけ 万骬切除法は Blair (1907)2) によって初めて䟕述された か，彼は手用の锯を使用して小齿部あるいは大日齿部 で骨切除を行っている，その後，下頻悄骨体部を切除す 万手術は Harsha (1912) ${ }^{3)}$, New 5 (1941)"), Dingman $(1944)^{5)}$, Thoma $(1963)^{6)}$ おび上野 $(1958)^{10)}$ などに よって行われてきた。

この方法は，1）メスによる切開部位から骨切除部位 までの距離が短く，2）下歯槽神释や功・静脈を保存し たまま，骨切除ができ， 3）骨切除部位の前方および後 方に骨植堅固な齿があるときには，下頻部の固定が容易 であって，4）下䫓前突症だけではなく，それに開咬が 合侀した症例にる適用でき，その高応範囲か厸い，など の利点を有するが，歯を锇牲にしなければならない場合 があり，下頻枝部の改善が得られないなどの欠点もある といわれている。

しかし，本学で行っているロ内法による両側下額骨骨 体部部分切除短縮術は，1）顔面に手術切創を作らな い，2）下歯槽神経や血管を切断しないか， a）知覚 麻疸や異和感は一時的なるのにすぎず，b）強固な固定

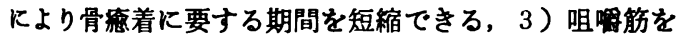
損伤しない，4）下影頭の変位がない，5）たとえ齿を 抜去しても，咬合を改善することによって，術後早期に 咬合機能の向上を促すことができ，異常咬合の再発を防 止することが可能である，などの長所をるっている。

\section{3. 研究方法について}

これまで行われてきた下額前突症の治療においては， 額態模型および頭部 $\mathbf{X}$ 線規格写真などを用いた分析結果 から下額骨の後退量が決定されており，しかもその治療 奻果の判定には形態の改善に重点が置かれていて，その 能についての検索は十分になされていなかった。

ところで，正常咬合者の咀緭リズムには規 則 性があ

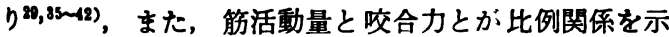
ナ(8,40)ことが報告されている。

そこで著者は，本症患者の術後の機能を把握する目的 て，咀唃運動時の筋活動について検討した，すなわち， 同一患者の術前と術後における咀嗂リズムと筋活動量と を比較するとともに，正常咬合者のそれとも比較検討し
た

な米，被㭘令品にはチューインガムを用いたが，それ

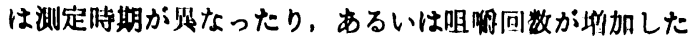
りしてもチューインガムの硬さや年が比校的一定して いるからである(1)

\section{4. 研究成練について}

1) 咀程りズム

Ahlgren (1966) ${ }^{953}$ は不正咬合者に打いては正常咬合者

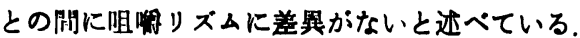

しかし，Perry (1955)44) はII 級 1 頪の症例では Cycle time が不規則であると報告しているし，延原 (1958) も下顆前突症患者においては，正常咬合者に比へて咀嘫 リズムの動据が大きいと述べている。

さらに，今井 (1975) ${ }^{377}$ は反対咬合を FKO によって 治等すると，咀婙リズムは一定化するといい，梅澤 (1976) ${ }^{309}$ は反対咬合を edge wise appliance によって 治亦すると，咀喂リズムは律動化して，正常咬合者に近 似した咀婙リズムを示すよらになると報告している。

また，広瀬 $(1974)^{36)}$ は下額前突症の学童を FKO, Chin cap あるいは影間固定によって治㞠すると，乱れ ていた咀噧リズムが安定したと報告しているし，中島ら (1975) ${ }^{83)}$ 反対咬合者には咀瀮リズムの乱れがあり，

FKO で治庵するとその乱れが少なくなる傾向を示した といっている.

また，小坂 $(1973)^{40}$ は，下頻前突症患者（術前と術 後）と正常咬合者との間には，咀㗪筋の筋電図において その Duration, Interval および Cycle time の各平均 值に有意差は認められなかったか，標準偏差には有意差 が翟められ，術前における咀哷リズムの乱れは術後に正 常化し，正常咬合者の咀哷リズムに近ついたと述べてい る.

著者の研究においては, 術前には Duration (7 例に おいて), Interval (4 例において) および Cycle time （8 例において）は対照群におけるよりる大きい值を示 し，あるいは大きい変動巾を示していたのが，手術によ ってそれらが短縮し，また変動巾も小さくなって対照群 の値に近くなり，術前と術後の間には明らかに有意差が 認められた。

そして，手術群の全症例および 対照群の全被検者の 平均値を比較しても，術前における Duration および Cycle time は対照群よりも大きく，術後における Duration は術前に比へてて短樎して, 対照群に近つ’く傾向 がみられた。

また, 術前の Cycle time における Duration の占め る割合（ 6 例において)は，対照群におけるよりる大きか ったが，術後には小さくなって対照群の值に近ついた。

ところで，不正咬合者に拈いて咀噒リズムが乱れてい ることの原因について，Kawamura ら (1957) ${ }^{48}$ は不正 咬合では咀噒時に歯や口腔軟組織が異常に強い刺滶を受 
けた結果であると述べている。一方，咀㘁りズムが改

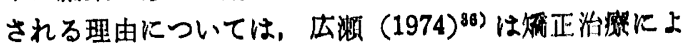

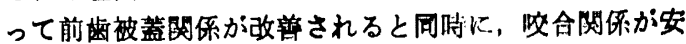
定する結果，主として歯出よび口際粘㬺に加わってい た異常刺潄が除去されたからであるといい，また小双 (1973) ${ }^{40}$ は下顆前突症患者の手術に上って影骨の形態が 変化するとともに珓合が安定する結果，各ストロークに おける咬合位の变動が少なくなり，固有受容器に加わる 刺放が単純化されたからであると報告している。

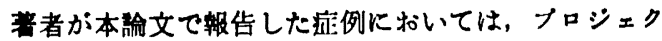
トチームによって決定した埥断扰よび治方方剑に基つ き，まず下䫑前突症の咬合を敒復することに点をおい て，ついで顔貌を改善する手術を行い，手街直後に，安

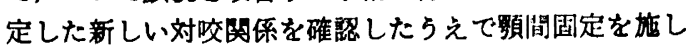
た. そして，顎間固定は約 1.5 か月で除去したか，上影 および下類の arch wire は新しい咬合威係に順応でき るよ5に，約 6 か月間影間コムを用いて能訓練を行った 後に除去した。

このよらな方法で治痖を行らと，筋訓練によって患者 は改善された，かつ安定した咬合状態において早く順応 できるよらになる結果, 咀噒時に口腔の各種感覚受容器 に加わっていた異常刺激が除去され，咀㩐筋の筋電図に おける Duration が正常になり，咀謝リズムが改良され たものと考えられる.

\section{2) 筋活動量}

柳田ら $(1956)^{50)}$ は片側に欠如齿のある患者に義雪を装 着すると，補緅側の咬筋の活動鲁が $2 \sim 3$ 倍になり, 対 側の筋活動量す著明に增加することを䘽察し，単海の治 療効果か対側にる及ぶと思われると述へ，橋本(1969) ${ }^{42)}$

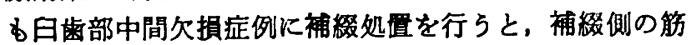
活動量が増大し，対側の筋活動量も補緅側に準して増加 する傾向のあることを報告している．

本研究においては，衍後には 6 被検筇（9例におい て), 咀曙側の 3 被検筋（9例において）および対側の 3 被検筇（7 例において）の各総活動量は, 術前におけ るよりも有意に增大した。

しかし, 手術群の全症例および対照群の全被検者の平 均値からみると, 筇活動量は手術群と奶照群との間には 有意差を認めなかった。

以上の事実は, 各症例間の筋活動量の差が大きいため に, 各症例別飞みると大部分の症例においては術前と術 後との間に有意差が認められたのに対して, 対照群およ び手術群との間, 術前と術後との平均値間には有意差は 認められなかったものと考えられる.

また，口内法による両側下䫑骨骨体部部分切除短樎術 を受けた下颗前突症患者の術前および術後の咀哷能率を 比較検討した岡野ら $(1976)^{15}$ の報告によると, $\overline{5 \mid 5}$ 部あ るいは $\overline{6 \mid 6}$ 部で切除してる，また $\overline{5 \mid 56}$ 部あるいは $\overline{65 \mid 5}$ 部において切除した場合です，咀嚼能率はいちじるしく
改帝されたと述へてているが，このことは著者が行った口

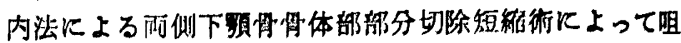

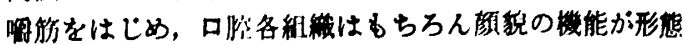
的にも改部された結果によるものと思われる。

\section{結的}

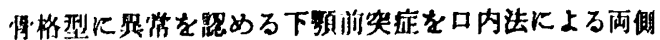

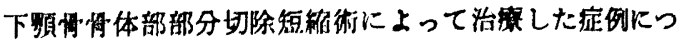

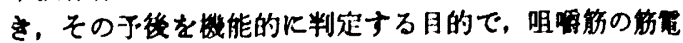

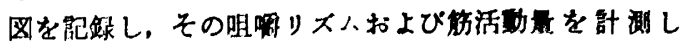
て, 次の結論を得た。

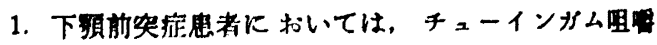

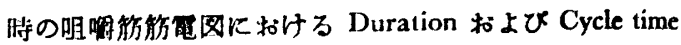
は，対照群に比敕して有意に艮く，その值の变轵る大き かった。

しかし、術後においては Duration および Cycle time は短樎し，その值の变動る小さくなって，付照群に和け る値に近ついた。 そして，Durationは術前と衍後との 間に有意差を認めた。

Interval においても, Duration および Cycle time と同傾向の結果を得たか，対照群と術前との間および街 前と衍後との間には，有意差は認められなかった。

2. Cycle time における Duration の占める钊合は, 術前では対照群に比へて有意に大きく，その值の変動る 大きかったか，術後には小さくなるととるにその值の変 動す小さくなり，対照群に近つく頋向を示した。

3. 6 被検筋の総活動量, 咀时側の 3 被検筋の活動 量および対僋の 3 被検筋の総活動量は, 術前には対照群 よりも小さかったが，術後には大きくなり，対照群の值 に近くなった。 また，大多数の症例において街前と術後 との間に有意差を認めた。しかし，手術群と対照群の平 均值間には，有意差は認められなかった。

以上のことから，下頻前突症患者に口内法による両侧

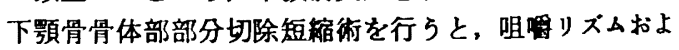
び筋活動量が正常咬合者とほぼ同じ値になることが咀噃 筋の筋電四から証明できた。

したかっって，本研究によって，下䫛前突症に対する口 内法による両側下額骨骨体部部分切除短樎術は形態的 に，また機能的にす咀啳機能を回復させることができる 適切な手術法であることを明らかにすることができた。

稿を終えるにあたり，こ指尊とこ校閲をいただいた岡 野博郎教授に、こ校閧を賜った本学㐘科補緅学教室第三 满座三谷春保教授に謝意を表わしますとともに，本研究 に際し種々こ指埒とこ協力をいただいた本学生理学教室 覚道幸男教授，芳本忍および杉村忠敬講師に感懒いたし ます。

また，本研究になにかとこ協力いただいたすロジェク 
トチームの各位およぴ教室員各位にお礼申しまげむす。

本論文の要旨は，第21回日本口腔外科学会稳会（昭和 51年10月10日，北九州）および第 262 回大阪科学会侧 会（昭和53年 6 月 10 日，大阪）において器表した。

\section{引用文 姑}

1) Hullihen, S.P.: Case of elongation of the under jaw and distortion of the face and neck, caused by a burn, successfully treated. Amer J Dent Sci 9: 1571849.

2) Blair, V.P.: Operation on the jaw-bone and face. Surg Gynec Obstet 4: 671907.

3) Harsha, W.H.: Bilateral resection of the jaw for prognathism. Surg Gynec Obstet 15: 51 1912.

4) New, G.B., et al.: The surgical correction of mandibular prognathism. Amer J Oral Surg 2: 21941.

5) Dingman, R.O.: Surgical correction of mandibular prognathism, an improved method. Amer J Orthodont Oral Surg 30: 6831944.

6) Thoma, K.H.: Oral surgery. ed 4, Mosby Co, St Louis, 1963, p 1131.

7) Obwegeser, H., et al.: The indication for surgical correction of mandibular deformity by the sagittal splitting technique. Brit $\mathrm{J}$ Oral Surg 1: 1571964.

8）岡田 : 下颜突出の外科的熎正に就いて，日 稪㐘誌 1：78 1932.

9）中村平藏，他：不正咬合の謂血手政14例の実施 成亚。監牀菌科 13: 1151941.

10）上野正：下影前突症と開咬に対する下额骨体 短糟行。形成外科 1:52 1958.

11）高橋庄二郎，他：下額枝矢状分割法による下穎 前突症手術について。 日外誌 17：528 1971.

12) Goldstein, A.: Appraisal of results of surgical correction of Class III malocclusions. Angle Orthodont 17: 591947.

13) Robinson, M., et al.: Prognathism questions in the surgical-orthodontic team. Amer J Orthodont 47: 5311961.

14) Mills, P.B.: The orthodontist's role in surgical correction of dentofacial deformities. Amer J Orthodont 56: 691969.

15）岡野博郎, 他：下頽前突症の治療の要点一特に プロシクトチームによる両側下䫑骨骨体部部 分切除短樎術。齿展望 48：541 1976.

16) Aaronson, S.A.: Cephalometric investigation of the surgical correction of mandibular prognathism. Angle Orthodont 37: 2511967.

17) Grimm, G. und Beithlich, E.: Kritische Bewertung der Operationsergebnisse von 101 Progeniefällen unter besonderer Berücksich- tigung des Verfahrens nach Obwegeser-Dal Pont. Dtsch Zahn-Mund-Kieferheilk 61: 295 1973.

18) Kelsey, C. C.: Radiographic cephalometric study of surgically corrected mandibular prognathism. J Oral Surg 26: 2391968.

19) Morrill, L.R., et al.: Surgical correction of mandibular prognathism. Amer J Orthodont 65: 5031974.

20) Poulton, D.R., et al.: Cephalometric X-ray evaluation of the vertical osteotomy correction of mandibular prognathism. Oral Surg Oral Med Oral Path 16: 8071963.

21) Reitzik, M.: Surgically corrected mandibular prognathism, a cephalometric analysis of fifty cases. Amer J Orthodont 66: 821974.

22) Reitzik, M. . Cephalometry in the surgical correction of prognathism. Brit J Oral Surg 16: 11972.

23) Simpson, W.: The results of surgery for mandibular prognathism. Brit J Oral Surg 12: 1661974.

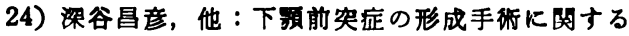
研究，特に形怨学的計剆値について。采院大齿 誌 8: 2001971.

25）伊藤利明：頭部 $X$ 線規格写真による下顥前突症 患者の顔面頭蓝に関する形態学的研究, とくに 外科的立場から。整科学報 77: 4091977.

26）深谷昌彦：下䫑前突症の手術に闺する研究. 口 科誌 23: 1751974

27) 花田浩治, 他 : Skeletal Class III malocclusion

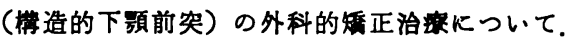
日稪莯誌 34: 961975.

28) Pruzansky, S.: The application of electromyography to dental research. J Amer Dent Ass 44: 491952.

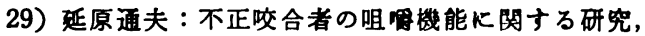

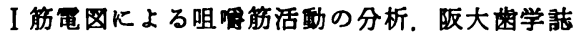
3: 631958

30) Liebman, F.M., et al.: An evaluation of electromyography in the study of the etiology of malocclusion. J Pros Dent 10: 10651960.

31) Grossman, W.J., et al.: Electromyography as an aid in diagnosis and treatment analysis. Amer J Orthodont 47: 4811961.

32) Moss, J.P., et al.: An electromyographic investigation and survey of Class III cases. $\mathrm{Tr}$ Br Soc Study Orthodont. John Wright and Sons Ltd, London, 1965, p 147.

33) Moss, J.P., et al.: An electromyographic investigation and survey of Class III cases. Dent Pract 16: 3491966.

34) Moss, J.P., et al.: An electromyographic investigation of patient with a normal jaw relationship and a Class III jaw relationship. 
Amer J Orthodont 66: 5381974.

35) Ahlgren, J.: Mechanism of mastication. Acta Odont Scand 24 supple 44: 51966.

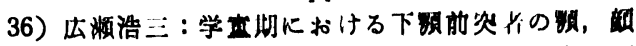

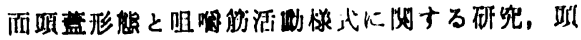

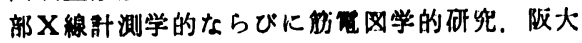

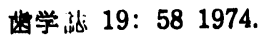

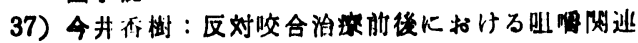

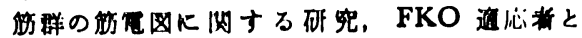
誟えられるむのについて，1大学 48: 720 1975.

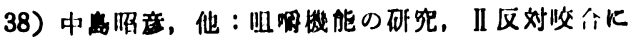

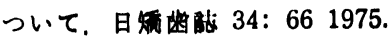

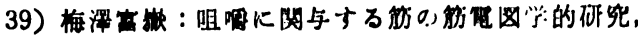

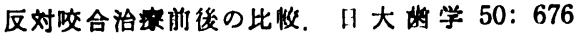
1976.

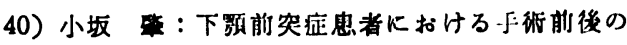
筋雪图学的研究。楼科学報 73: 7151973.

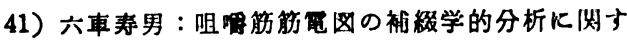
万研究。科医学 28: 6151965.

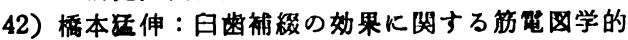
研究. 科医学 32: 581969.

43) Sanborn, R.T.: Difference between the facial skcletal patterns Class III malocclusion and nurual occlusion. Angle Orthodont 25: 208 1955.

44) Perry, H.T.: Finctional electromyography of thie temporal and masseter muscles in Class II, divivion 1 malocclusion and excellent occlusion. Angle Orthodont 25: 491955.

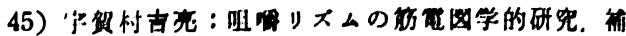
䊅, 16: 221973.

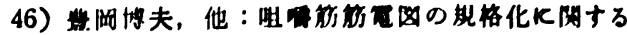

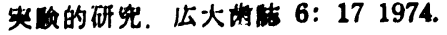

47) Inman, V.T., et al.: Relation of human electromyogram to muscular tension E.E.G. Clin Neurophysiol 4: 1871952.

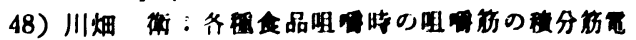
因について。科医学 32: 4531969.

49) Kawamura, Y., et al.: Studics on masticatory function 1. An electromyographic analysis of the chewing pattern of the normal occlusion and malocclusion. Med J Osaka Univ 8: 2291957.

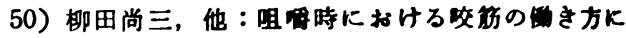

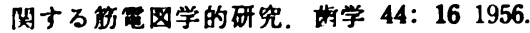

